\title{
Sosa v. Alvarez-Machain and Human Rights Claims Against Corporations Under the Alien Tort Statute
}

Carlos Manuel Vázquez

Georgetown University Law Center, vazquez@law.georgetown.edu

Georgetown Public Law and Legal Theory Research Paper No. 12-077

This paper can be downloaded free of charge from:

https://scholarship.law.georgetown.edu/facpub/1056

http://ssrn.com/abstract=844350

Carlos Manual Vázquez, Sosa v Alvarez-Machain and Human Rights Claims Against Corporations Under the Alien Tort Statute in HUMAN RIGHTS AND INTERNATIONAL TRADE 137-147 (Thomas Cottier, Joost Pauwelyn \& Elisabeth Bürgi Bonanomi eds., Oxford: Oxford University Press 2005)

This open-access article is brought to you by the Georgetown Law Library. Posted with permission of the author. Follow this and additional works at: https://scholarship.law.georgetown.edu/facpub

Part of the Business Organizations Law Commons, Human Rights Law Commons, International Law Commons, and the Torts Commons 


\title{
Sosa v Alvarez-Machain and Human Rights Claims against Corporations under the Alien Tort Statute
}

\author{
CARLOS MANUEL VÁZQUEZ
}

When the Supreme Court's decision in Sosa v Alvarez-Machain ${ }^{1}$ was handed down, some believed that the case sounded the death knell for the use of the Alien Tort Statute ${ }^{2}$ to maintain human rights claims against private corporations in the courts of the United States. ${ }^{3}$ These claims seem to me to be overstated. The decision clarifies the nature of claims under the Alien Tort Statute to some extent, and places some limits on the theories available in actions against private corporations, but for the most part such suits remain as viable after Sosa as they were before. Unocal's recent decision to settle the claims against it for human rights violations in Burma ${ }^{4}$ is perhaps an implicit recognition that Sosa did not doom such claims.

That is not to say, however, that victims of corporate human rights violations in developing countries should hold out much hope that their lot will be bettered through Alien Tort Statute litigation in the United States. Even before Sosa, such suits had a chance of producing results favourable to foreign plaintiffs only with respect to a very narrow category of human rights violations. Suits under the Alien Tort Statute were never a very promising mechanism for addressing the problem of human rights violations caused by corporate conduct abroad.

This paper first briefly describes the evolution of the Alien Tort Statute from the time it was reinvigorated in Filartiga $v$ Peña-Irala ${ }^{5}$ to the Supreme Court's decision in Sosa. It then discusses the implications of Sosa for human rights claims against private corporations and assesses the potential significance of federal human rights litigation as a mechanism for addressing the problems of those whose human rights are adversely affected by US corporations operating abroad.

The Alien Tort Statute was enacted in 1789 as part of the United States' First Judiciary Act. ${ }^{6}$ It provides that the federal courts shall have jurisdiction over 'any civil action by an alien for a tort only, committed in violation of the law of nations or a treaty of the United States'.7 There is little direct evidence of the

1124 S. Ct. 2739 (2004). 228 U.S.C. $\$ 1350(2000)$.

${ }^{3}$ R S Greenberger/P W Tam, Human Rights Suits Against U.S. Firms Curbed, Wall Street Journal (30 June 2004) A3; W Richey, Ruling Makes it Harder for Foreigners to Sue in US Courts, Christian Science Monitor (30 June 2004) 3.

${ }^{4}$ E Alden et al, Unocal Pays Out in Burma Abuse Case, Financial Times (14 December 2004) 12 (quoting the plaintiffs' lawyer as stating that the settlement was 'going to do some great things for the victims in Burma').

5 630 F.2d 876, 2d Cir. (1980).

6 Judiciary Act of 1789, ch 20, \$9(b), 1 Stat. 73, 77 (1789) (codified as amended 28 U.S.C. $\$ 1350(2000))$.

728 U.S.C. $\$ 1350$. 
sorts of actions the framers of the statute intended it to cover. Judge Friendly called it a 'legal Lohengrin' because 'no one seems to know whence it came'. For most of the country's history, the statute lay dormant. The US Court of Appeals for the Second Circuit breathed life into the statute in 1980 in the Filartiga case. The court there found that the statute conferred jurisdiction over a suit by the sister and father of a Paraguayan who had been tortured in Paraguay by the defendant, a low-level Paraguayan official who was then living in New York. ${ }^{9}$ The court held that jurisdiction existed because the plaintiffs were aliens and they were suing for a tort committed in violation of international law. The bulk of the opinion addressed whether torture violated international law, and the court concluded that it did. It wrote that 'for purposes of civil liability, the torturer has become-like the pirate and slave trader before him-hostis bumani generis, an enemy of all mankind'. ${ }^{10}$

Filártiga exemplifies the least controversial category of contemporary human rights lawsuit under the Alien Tort Statute. The defendant was the person who had personally perpetrated the acts complained of, and those acts violated clearly established norms of international human rights law. Subsequent litigants pushed the envelope in several directions. Suits were brought against persons who authorized or failed to prevent violations of human rights norms, but did not personally commit them. ${ }^{11}$ Others were brought against entities that were not recognized states, ${ }^{12}$ or officials of such entities. ${ }^{13}$ Suits were brought alleging violations of less-established principles of international law. ${ }^{14}$ Some of these suits survived motions to dismiss; others did not.

As long as only foreign officials were being sued, human rights litigation under the Alien Tort Statute did not excite significant opposition, except within a segment of legal academia. ${ }^{15}$ In fact, Congress codified this line of cases, and extended the right of action to citizens, when it enacted the Torture Victim Protection Act. ${ }^{16}$ The lack of opposition may have had something to do with the fact that the defendants typically left the country or were expelled after being served with the complaint, ${ }^{17}$ and as a consequence the suits that were not dismissed at the threshold usually wound up producing default judgments that, with few exceptions, were never collected. Thus, although these lawsuits

${ }^{8}$ ITT $\nu$ Vencap, Ltd., 519 F.2d 1001, 1015, 2d Cir. (1975).

9 Filartiga $v$ Pena-Irala, 630 F.2d at $887 . \quad 10$ ibid.

11 See Hilao $v$ Estate of Marcos, 103 F.3d 789, 9th Cir. (1996); Xuncax $v$ Gramajo, 886 F. Supp. 162, 171-75, D. Mass. (1995).

${ }_{12}$ Tel-Oren $v$ Libyan Arab Republic, 726 F.2d 774, D.C. Cir. (1984).

13 Kadic v Karadzic, 70 F.3d 232, 2d Cir. (1995), cert. denied, 518 U.S. 1005 (1996).

${ }^{14}$ Flores $v$ Southern Peru Copper Corp., 343 F.3d 140, $2 \mathrm{~d}$ Cir. (2003) (environmental harm); TelOren, 726 F.2d 774 (terrorism).

1s See C A Bradley/J L Goldsmith, III, The Current Illegitimacy of International Human Rights Litigation, 66 Fordham Law Review 319, 358-359 (1997); J M Simon, The Alien Tort Claims Act: Justice or Show Trials?, 11 Boston University International Law Journal 1 (1993).

16 Codified in a note to 28 U.S.C. $\$ 1350$.

17 eg Paul $v$ Avril, 901 F. Supp. 330, S.D.Fla. (1994); Todd $v$ Panjaitan, No 92-12255, 1994 WL 827111, D. Mass. (26 October 1994). 
showed the United States' abhorrence of the conduct of the defendants, and also gave victims a forum for the ventilation of their claims and deterred foreign torturers from travelling to the United States, they did not generally provide compensation to the victims. The lawsuits served a largely expressive function, and the costs were borne largely by foreign plaintiffs (and the human rights organizations representing them) and, where the defendant did not default, by foreign individuals guilty of gruesome acts.

Litigation under the Alien Tort Statute began attracting significant attention outside the human rights community when the lawsuits began targeting US corporations that were alleged to have aided and abetted foreign states in violating international law, or to have committed violations of international law directly themselves. The best known of these cases is Doe $v$ Unocal. ${ }^{18}$ The plaintiffs were Burmese villagers who alleged that the US corporation Unocal had made use of forced labour in connection with its Yamada Pipeline project in Burma. A panel of the US Court of Appeals for the Ninth Circuit allowed the case to proceed on two alternative theories. First, it held that the international law norm prohibiting forced labour was 'among the "handful of crimes...to which the law of nations attributes individual liability," such that state action is not required'. ${ }^{19}$ Secondly, it held that Unocal could be held liable for aiding and abetting the Burmese government's violations of the plaintiffs' human rights if Unocal's conduct violated international law norms prohibiting aiding and abetting. ${ }^{20}$ Judge Reinhardt concurred, but differed with the majority regarding the law that determined Unocal's liability for aiding and abetting. In the view of Judge Reinhardt, plaintiffs did not have to establish that Unocal's conduct violated international law. If the Burmese government's conduct violated international law, 'the ancillary legal question of Unocal's third-party tort liability should be resolved by applying general federal common law tort principles, such as agency, joint venture, or reckless disregard'. ${ }^{21}$

This and other lawsuits against US corporations ${ }^{22}$ produced a backlash against the Alien Tort Statute. Books about the Alien Tort Statute began appearing with titles such as Awakening Monster. ${ }^{23}$ The executive branch, which had sided with the plaintiffs in prior ATS cases, ${ }^{24}$ began arguing that Filártiga had been wrongly decided. The United States filed an amicus brief supporting en banc review in Unocal, arguing that the Alien Tort Statute is

182002 U.S. App. LEXIS 19263.

19 ibid (quoting Tel-Oren v Libyan Arab Republic, 726 F.2d 774, 794-95, D.C. Cir. (1984)) (J Edwards, concurring).

21 ibid (J Reinhardt, concurring).

22 eg Wiwa v Royal Dutch Petroleum Co., 226 F.3d 88, 2d Cir. (2000); Villeda Aldana v Fresh Del Monte Produce, Inc., 305 F. Supp. 2d 1285, S.D. Fla. (2003); Estate of Rodriguez v Drummond Co., 256 F. Supp. 2d 1250, N.D. Ala. (2003); Presbyterian Church of Sudav Talisman Energy, Inc., 244 F. Supp. 2d 289, S.D.N.Y. (2003); Abdullabi v Pfizer, Inc. (2002) U.S. Dist. LEXIS 17436, S.D.N.Y. (2002); Sarei v Rio Tinto Ltd., 221 F. Supp. 2d 1116, C.D. Cal. (2002).

${ }_{23}$ G C Hufbauer/N K Mitrokostas, Awakening Monster: The Alien Tort Statute of 1789 (2003).

24 See Memorandum for the United States as Amicus Curiae, Filartigav Pena-Irala, 630 F.2d 876, $2 \mathrm{~d}$ Cir. (1980). 
purely a jurisdictional statute, that it does not create a right of action, and that a right of action for claims relying on customary international law may be maintained only if other statutes-such as the Torture Victim Protection Actcreate a right of action. ${ }^{25}$ (The Court of Appeals granted the petition for rehearing en banc and vacated the panel's decision. ${ }^{26}$ ) The United States took a similarly broad position in its amicus brief in Sosa $v$ Alvarez-Machain, even though narrower arguments would have sufficed to deny relief in that case. ${ }^{27}$ Had the Court agreed, Filartiga itself would have been effectively overruled and the Alien Tort Statute would have returned to its somnolent pre-Filártiga state.

The Supreme Court in Sosa rejected the United States' interpretation. Rather than reverse Filartiga, it cited it with approval and left the door ajar for the use of the Alien Tort Statute to challenge human rights abuses. ${ }^{28}$ But the Court enjoined the courts to be 'vigilant doorkeep[ers]'..$^{29}$ The Court held that the Alien Tort Statute was purely jurisdictional, meaning that the right of action must have its source elsewhere. However, rather than requiring a federal statutory source for the right of action, such as the Torture Victim Protection Act, the Court recognized a power in the federal courts to enforce a 'limited category' of norms of customary international law as a matter of federal common law. ${ }^{30}$ It recognized that, at the time the Alien Tort Statute was enacted, customary international law was regarded as part of the common law and enforceable as such in the courts without prior transformation into domestic law by statute. The Court concluded that the framers of the statute meant to authorize the adjudication in federal court of a "narrow set of violations of the law of nations, admitting of a judicial remedy and at the same time threatening serious consequences in international affairs' ${ }^{31}$ 'Uppermost in the legislative mind appears to have been offences against ambassadors; violations of safe conduct were probably understood to be actionable, and individual actions arising out of prize captures and piracy may well have also been contemplated. ${ }^{32}$ After considering a number of reasons counselling caution in adapting the expectations of the statute's framers to today's world, in which the common law is understood very differently from in the past and customary international law has a very different content, the Court held that the courts "should not recognize private claims under federal common law for violations of any international law norm with less definite content and acceptance among civilized nations than the historical paradigms familiar when [the Alien Tort Statute] was enacted'. ${ }^{33}$

Although the Court did not say that the courts should always recognize private claims for violations of international law norms with content that is as

25 Brief for the United States as Amicus Curiae, Doe v Unocal Corp., 9th Cir. (2002) (Nos 00-56603, 00-56628).

${ }^{26}$ Doe $v$ Unocal (2003) U.S. App. LEXIS 2716, 9th Cir. (14 February 2003).

${ }^{27}$ See Reply Brief for the United States as respondent Supporting Petitioner, Sosa $v$ AlvarezMachain, 124 S. Ct. 2739 (2004) (No 03-339); Brief of the United States as Respondent Supporting Petitioner, Sosa v Alvarez-Machain, 124 S. Ct. 2739 (2004) (No 03-339).
28 Sosa, 124 S. Ct. 2764.
29 ibid.
30 ibid 2754.
31 ibid 2756.

32 ibid 2759. 
definite as the historical paradigms, I think it is fair to read the opinion as contemplating that such claims should ordinarily be recognized, subject to possible limiting doctrines of a procedural nature, such as exhaustion of remedies, or case-specific deference to foreign policy concerns of the executive branch. In a footnote, the Court stated that the 'requirement of clear definition is not meant to be the only principle limiting the availability of relief in the federal courts for violations of customary international law', and listed exhaustion of remedies and deference to the executive as possible additional limitations. ${ }^{34}$ The Court did not limit the possible limitations to those two, nor did it adopt those two limitations. The two are therefore merely illustrations of the sort of limitations the Court has in mind. Significantly, neither relates to the nature of the international law obligation that was violated.

That international law norms that protect individuals and are of definite content and wide acceptance will generally be enforceable through federal common law actions under Sosa is strongly suggested by the Court's statement that the approach it was adopting is generally consistent with the reasoning of many of the courts and judges who faced the issue before it reached this Court'. ${ }^{35}$ The Court cited Filartiga with approval for the proposition that 'the torturer has become-like the pirate and slave trader before him-bostis bumani generis, an enemy of all mankind'. ${ }^{36}$ It also cited Judge Edwards' statement in Tel-Oren that the 'limits of section 1350's reach' should be defined by a handful of heinous actions-each of which violates definable, universal and obligatory norms', ${ }^{37}$ and the holding of In re Estate of Marcos Human Rights Litigation that '[a]ctionable violations of international law must be of a norm that is specific, universal, and obligatory'. ${ }^{38}$ The opinion thus appears to approve of the Filartiga line of cases as it had been applied by most lower courts until that point.

One of the open questions after the Sosa decision concerns the extent to which the Alien Tort Statute remains available as a source of jurisdiction over suits against private corporations. Some commentators have read the Court's opinion as sounding the death knell to such suits, ${ }^{39}$ while others believe that Sosa blesses them. ${ }^{40}$ In my view, Sosa does neither. The Court referred to suits against corporations only in a footnote, in which it said that ' $[a]$ related consideration [related, apparently, to whether the international-law norm is sufficiently well-established] is whether international law extends the scope of liability for a violation of a given norm to the perpetrator being sued, if the defendant is a private actor such as a corporation or individual'. ${ }^{41}$ The footnote does not rule out the possibility that private corporations might be subject to

34 ibid 2766 fn $21 . \quad 35$ ibid 2765-66.

36 ibid 2766 (quoting Filartiga, 630 F.2d at 890). $\quad 37$ Tel-Oren, 726 F.2d at 781.

38 In re Estate of Ferdinand Marcos, 25 F.3d 1467, 1475, 9th Cir. (1994). ${ }_{39}$ See n 3.

40 See R Gertner, Human Rights Claims Against Corporations May Go Forward, Law Wkly. USA (19 July 2004) at 1 (quoting W Aceves, a professor who submitted an amicus brief in support of Alvarez, stating that the court 'has given a green light to litigation under the Alien Tort Statute').

41 Sosa, 124 S. Ct. at $2766 \mathrm{fn} 20$. 
federal common law rights of action for violations of customary international law. Indeed, one of the two cases the Court cited in this footnote, without disapproval, held that a suit could be maintained under the Alien Tort Statute against a 'private actor' alleged to have committed genocide. ${ }^{42}$ That Unocal does not believe that Sosa precludes Alien Tort Statute suits against private corporations is suggested by its recent decision to settle the Unocal case for an undisclosed sum that reportedly 'thrilled' the plaintiffs' lawyers. ${ }^{43}$

Sosa also sheds some light on the issue that divided the panel in Unocal. The majority held that, if the plaintiff did not rely on a norm of international law directly applicable to private parties, an ATS action could succeed against a private party only if principles of international law imposed liability on the private party for aiding and abetting the state's violation of international law. Judge Reinhardt maintained that, if the plaintiff could establish a violation of an international legal norm by the state, the private party could be found liable for aiding and abetting under federal common law. The Supreme Court's analysis in Sosa seems closer to Judge Reinhardt's than to that of the Unocal majority, although that analysis may well lead to the conclusion reached by the majority.

For the Sosa majority, the liability of a defendant in an ATS case results from a combination of international law and federal common law. The opinion strongly suggests that the courts are to look to international law to determine whether a primary rule of international law has been violated. If such a violation has occurred, the existence of a secondary rule entitling the plaintiff to relief is a matter of judge-made federal common law. ${ }^{44}$ Consistent with this interpretation the Court speaks of the judicial 'creation of a federal remedy"45 or 'the creation by judges of a private cause of action to enforce... the rule [of customary international law]'. ${ }^{46}$ Similarly, in rejecting Alvarez's arbitrary detention claim, the Court notes that he invoked a 'broad principle' that reflects an 'aspiration' rather than an established rule of law, and it concluded that '[c]reating a private cause of action to further that aspiration would go beyond any residual common law discretion we think it appropriate to exercise' ${ }^{47}$ The implication is that it is appropriate for the courts to create a remedy for injuries caused by conduct that violates well-defined and well-established norms of international law. If so, the Unocal majority was too demanding in insisting that the plaintiff must establish that international law imposes individual

${ }^{42}$ See Kadic $v$ Karadzic, 70 F.3d 232, 239-241, 2d Cir. (1995), cited in Sosa, 124 S. Ct. at 2766 (describing Kadic as holding that there was a 'sufficient consensus in 1995 that genocide by private actors violates international law').

${ }^{43}$ See L Girion, Unocal To Settle Rights Claims, L.A. Times (14 December 2004).

44 In international legal discourse, 'secondary rules' are those that specify the legal consequences of a breach of the primary rules. On the distinction between the primary and secondary rules of international law, see Commentaries to the Draft Articles on Responsibility of States for Internationally Wrongful Acts, U.N. GAOR, 56th Sess., Supp. No 10, Comment 1, U.N. Doc A/56/10 (2001).

${ }^{46}$ ibid $2769 \mathrm{fn} 29$ (emphasis supplied).

45 Sosa, 2767 (emphasis supplied).

47 ibid 2767 (fns omitted; emphasis supplied). 
liability for the acts committed by the defendant. The defendant's liability is a matter of secondary or remedial law. As Judge Reinhardt wrote, 'international law applies to determine whether a violation has occurred'. ${ }^{48}$ If there has been a violation of international law, it is for the Court to create a remedy in appropriate circumstances.

It is true that the Court in Sosa indicated that the question "whether international law extends the scope of liability for a violation of a given norm to the perpetrator being sued' would be a 'consideration' 'if the defendant [were] a private actor such as a corporation or individual'. ${ }^{49}$ Although its use of the term 'liability' here does suggest that international law determines the remedy as well as the violation, I doubt that that is what the Court meant. The cases it cited to illustrate the point both involved, in the Court's own description, whether primary norms of international law were 'violate[d]' ${ }^{50}$ Moreover, the Court's statement that this is a 'consideration' may just mean that it is sufficient but not necessary that international law impose individual liability. Thus, despite this footnote, the thrust of the Court's analysis is consistent with Judge Reinhardt's conclusion that, in ATS cases, the rules governing primary conduct come from international law, while the secondary, or remedial, rules are a matter of federal common law.

On the other hand, the Supreme Court might well reject Judge Reinhardt's specific conclusion that the 'aiding and abetting' standards that apply in ATS cases come from federal common law rather than international law. If the Court in Sosa held that international law supplies the primary rules while federal common law supplies the secondary rules, it may follow that the plaintiff must establish that the defendant's conduct violated international law. Aiding and abetting standards may relate to primary rules of international law, if one defines primary rules as those that determine whether the defendant committed a violation of the law in the first place. Thus, if the norm that was allegedly violated is one that only applies to state action, the plaintiff may have to show that the private defendant 'aided and abetted' the violation under international law standards. Under this approach, private parties could be subjected to liability in ATS cases if they violated international law norms that apply to private parties, or if they aided and abetted a state's violation under international law standards.

It is of course possible that later cases may rule out the judicial creation of rights of action against private parties altogether. The Court, after all, urged caution and gave a non-exhaustive list of illustrations of possible additional limitations. But the Court gave no affirmative support to a rule barring the recognition of a private right of action against private corporations that violate norms of international law that are sufficiently defined and established. Thus, the Alien Tort Statute remains available as a basis for human rights suits against private corporations, although, in the light of Sosa's holding that the ATS is

48 Unocal (J Reinhardt, concurring).

50 Ibid.

49 Sos $a$ at $2766 \mathrm{fn} .20$ (emphasis supplied). 
purely jurisdictional, such suits should probably be called 'federal common law' actions rather than Alien Tort Statute actions. ${ }^{51}$

Even though human rights claims against private corporations remain available after Sosa, it cannot be said that the Alien Tort Statute offers much hope for redress for people from developing countries whose human rights have been adversely affected by private corporations. First, most international law norms regarding human rights do not apply directly to private businesses. The Unocal case implicated one of only a 'handful' of norms that has a plausible claim to being applicable to private entities-the norm prohibiting forced labour, which the panel in Unocal viewed as the contemporary version of the norm prohibiting slavery. With respect to other norms, corporations could be held liable in ATS lawsuits, at best, only through an aiding and abetting theory. The question whether the international law standards for aiding and abetting must meet the Sosa standard of being well-established and well-defined and, if so, whether they do meet that standard, was before the Court of Appeals in Unocal at the time the settlement agreement was reached. The United States submitted an amicus brief arguing that the standard does apply and was not met. ${ }^{52}$ Regardless of how that issue is ultimately decided, the prospect of maintaining lawsuits against private corporations for human rights violations under an aiding and abetting theory would remain quite narrow. Liability as an aider and abettor would appear to be available at best only when the state is the principal culprit and the corporation the enabler. That will be the case, I suspect, only in a very small proportion of the situations in which human rights are threatened by private corporations.

Not everyone agrees that only a handful of international human rights norms impose obligations directly on private actors, such as corporations. A different view is reflected in a document titled 'Norms on the Responsibilities of Transnational Corporations and Other Business Enterprises with Regard to Human Rights', which was adopted in August 2003 by the Sub-commission on the Promotion and Protection of Human Rights of the UN Commission on Human Rights, ${ }^{53}$ but was tabled by the Commission in August 2004 for further discussion. ${ }^{54}$ This document sets forth a lengthy list of obligations of private

s1 Even though the Court took pains to clarify that it regarded the Alien Tort Statute as purely jurisdictional, and the private right of action as federal common law, it is not clear to me that there is much practical difference between its holding and a holding that the private right of action has its basis in the Alien Tort Statute. The right of action clearly does have its basis in the Alien Tort Statute in the sense that the Court relied on the expectations of the framers of that statute to approve the judicial recognition of private rights of action to enforce norms of customary international law as a matter of federal common law.

${ }_{52}$ Supplemental Brief for the United States of America as Amicus Curiae in Doev Unocal Corp., Nos 00-56603, 00-56628 (dated August 2004).

${ }_{53}$ UN Doc E/CN.4/Sub.2/2003/12/Rev.2 (2003) [hereinafter Norms'].

${ }^{54}$ See A Blyth, Compromise deal reached on UN Norms, Ethical Corporation (21 April 2004) available at http://www.ethicalcorp.com/content.asp?ContentID=1947; B Hearne, Proposed UN Norms on human rights shelved in favor of more study, Ethical Corporation ( 3 May 2004) available at http://www.ethicalcorp.com/content.asp?ContentID $=1981$. 
corporations under international law. The document does not make it entirely clear whether it was meant to reflect existing international law or instead to furnish a basis for the development of international law. In my view, it does a bit of both. A few of the obligations set forth in the document do apply directly to private actors. These include the prohibition of forced labour, already discussed, and the prohibition of genocide. ${ }^{55}$ But most of the obligations set forth in the document apply to private actors, at best, indirectly. ${ }^{56}$ This is the case, for example, with respect to the anti-corruption provisions, ${ }^{57}$ which are based on conventions that require states to enact laws prohibiting certain acts by private actors. ${ }^{58}$ Similarly, the antidiscrimination norm ${ }^{59}$ appear to be indirectly applicable to private actors, insofar as they are based on the UN conventions addressing race and gender discrimination. ${ }^{60}$

Other human rights norms to which the Norms purports to hold private corporations seem difficult to apply to the conduct of private entities at all. For example, the Norms provide that ' $[\mathrm{t}] \mathrm{ransnational} \mathrm{corporations} \mathrm{and} \mathrm{other}$ business enterprises shall respect economic, social and cultural rights as well as civil and political rights and contribute to their realization, in particular the rights to development, adequate food and drinking water, the highest attainable standard of physical and mental health, adequate housing, privacy, education, freedom of thought, conscience, and religion and freedom of opinion and expression' ${ }^{61}$ The content of the obligation to 'contribute to [the] realization' of economic and social rights is difficult to ascertain, given that, under the Convention on Economic, Social, and Cultural Rights, these rights are subject to progressive realization, meaning that the parties to the convention are required to 'take steps to the maximum extent of their available resources, with a view to achieving progressively the full realization of the rights recognized in the Covenant '. ${ }^{62}$ The obligation to realize these rights progressively necessarily recognizes that there are a number of conflicting demands on a state's resources. Is it envisioned that a private corporation would have similar discretion to balance the competing demands on its resources? Is the demand to make a profit to survive in the unforgiving global marketplace to be taken into account in determining how much of the corporation's resources are available? Do the Norms reflect the belief that international law draws a line between appropriate and excessive profits? In short, translating an obligation of states to an

s5 Norms (n 53) Art 3.

56 See Generally Carlos M Vázquez, Direct vs. Indirect Obligations of Corporations Under International Law, 43 Colum. J. Transnational Law 927 (2005).

57 Norms (n 53) Art 11.

${ }_{58}$ See Convention on Combating Bribery of Foreign Public Officials in International Business Transactions (17 December 1997) Arts 1, 2, 4, 37 I.L.M.1.

59 Norms (n 53) Art 2.

${ }^{60}$ Convention on the Elimination of All Forms of Racial Discrimination, Art 2(1)(d) 28 September 1966) 660 U.N.T.S. 195, 5 I.L.M. 352; Convention on the Elimination of Discrimination Against Women, Art (2)(e), G.A. Res. 34/180, UN GAOR, 34th Sess., Supp. No 46 at 193, UN Doc A/RES/34/180 (1979) (entered into force 3 September 1981).

61 Norms (n 53) Art 12.

${ }^{62}$ International Covenant on Economic, Social, and Cultural Rights, G.A. Res. 2200, UN GAOR, 21st Sess, Supp. No 16 at 49, UN Doc A/6316 (1966). 
obligation of private enterprises poses especially severe challenges in the case of economic and social rights.

Yet it is economic and social rights that preoccupy those who advocate expanding the obligations of private corporations under international law. Such arguments tend to emphasize the economic power of corporations in today's world, which dwarfs that of many sovereign countries and enables the corporations to force economic concessions from developing countries. Because such countries cannot protect their citizens against such powerful economic forces, it is argued, the international community must step in.$^{63}$ If the case for direct international regulation of private corporations by international law is based on this economic imbalance of powers, it seems to reflect primarily a concern about the protection of economic and social rights, broadly understood. Yet it is these rights that are least likely to be enforceable in US courts through the Alien Tort Statute. Not only is the application of these norms to private corporations most problematic in this context, even the obligations of states in this area are rather ill-defined.

Nor is there much ground for optimism that the ATS will be expanded to make such rights judicially enforceable by aliens against US corporations. The interests that would be burdened by such an extension of the ATS are politically and economically powerful business entities in the United States. Those primarily benefited are relatively powerless individuals in foreign countries, who lack a voice in the American political process. Indeed, the United States is not even a party to the Covenant on Economic and Social Rights. The possibility that any developed country will significantly burden its own businesses for the benefit of the downtrodden in other countries seems remote.

It also seems unlikely that the international community will address this problem in the manner seemingly contemplated by the Norms-that is, through the articulation and enforcement of international law obligations directly on private corporations. Most who argue for extending international law to private corporations appear to view international articulation and enforcement of such norms as a supplement to national regulation rather than a threat to state sovereignty. ${ }^{64}$ This overlooks the fact that direct international regulation of private entities would represent a significant loss of power for states, which otherwise would retain control of compliance with international law. Such a move would make international law more effective, but it would do so by circumventing states. It is for this reason that the international law obligations that are recognized to apply directly to private parties do not exceed a handful. Attempts to expand the number are likely to face significant resistance.

63 eg S R Ratner, Corporations and Human Rights: A Theory of Legal Responsibility, 111 Yale Law Journal (2001) 443, 461-62.

64 This seems true of the UN Norms themselves, which, while articulating the obligations of corporations directly under international law and calling for international enforcement mechanisms, see UN Norms (n 53) Art 16, affirm that states have the primary duty to protect human rights. See ibid Arts 1, 17, 19. 
If so, then any international regulation of corporations is likely to be indirect. In other words, it is likely to take the form of treaties imposing on states the obligation to regulate corporations in certain ways. Many such treaties already exist, but they typically contemplate that states will regulate the conduct of corporations in their own territory, not extraterritorially. ${ }^{65}$ A state could conceivably decide to enforce these norms extraterritorially, subject to norms of international law that might limit its ability to do so, such as those regarding free trade. But, for reasons already discussed, there may not be much basis for optimism that they will do so to any significant extent. It may be more promising for those of us concerned with the lot of the poor in developing countries to focus more of our efforts on building the will and capacity of the governments of developing countries to protect the interests of their citizens through national or multinational regulation of private corporations doing business in their territories.

65 See, eg, conventions cited above ( $\mathrm{n} 60$ ). 